\title{
DETAILS OF THE HORSE BRIDLE FROM THE BURIAL OF THE SARMATIAN HORSEMAN FROM KOVALEVKA KURGAN CEMETERY
}

\author{
Valeriy M. Klepikov \\ Volgograd State University, Volgograd, Russian Federation \\ Mikhail V. Krivosheev \\ Volgograd State University, Volgograd, Russian Federation
}

\begin{abstract}
Introduction. The article publishes and analyzes the materials founded by the kurgan research near the village of Kovalevka in the southern part of the Volga-Don interfluve. Kurgan No. 13 is part of a kurgan cemetery, where the burials look relatively simultaneous and can be interpreted as a cemetery of nomadic migrants, settled in this territory in the confrontation with other Sarmatian groups. Methods. The authors pay special attention to the details of the horse bridle, to the type of the bits and cheek-pieces, and to the plaques, which decorated the straps of the headband. The traditional method of analogies is used for the analysis and interpretation of the material. Analysis. The type of rod cheek-pieces with two rectangular loops for fixing the rein in the central part and disc-shaped tips at the ends became widespread in the Sarmatian environment at the turn of the era. The cheekpieces and plaques were decorated with gold foil applications. Such burials are known in the Lower and Middle Volga region, Lower, Middle and Upper Don region, Kuban and in the Crimea. The authors find the origins of the tradition of making and using bits and cheek-pieces of this type in the East, in the regions of Transbaikal, Tuva, Altai and Northern China. The analysis of the bridle allows making the conclusion that it belonged to professional warriors-riders of upscale status. Results. The appearance of such burials coincides with the process of changing Sarmatian cultures at the turn of the eras, and probably the horsemen were active participants in these historical changes. However, it is impossible to define them as an ethnic group, or even to combine them within one archaeological culture. Therefore, the authors propose to see such riders as representatives of an intertribal aristocratic military group.
\end{abstract}

Key words: Volga-Don interfluve, horse bridle, bits, cheek-pieces, phaleras, horse warrior.

Citation. Klepikov V.M., Krivosheev M.V. Details of the Horse Bridle from the Burial of the Sarmatian Horseman from Kovalevka Kurgan Cemetery. Vestnik Volgogradskogo gosudarstvennogo universiteta. Seriya 4. Istoriya. Regionovedenie. Mezhdunarodnye otnosheniya [Science Journal of Volgograd State University. History. Area Studies. International Relations], 2020, vol. 25, no. 4, pp. 181-199. (in Russian). DOI: https://doi.org/10.15688/ jvolsu4.2020.4.12

УДК 930.26(470+571):636.083.7

Дата поступления статьи: 24.04.2020

ББК $63.48(2)-41.3$

Дата принятия статьи: 20.05.2020

\section{ДЕТАЛИ КОНСКОЙ УЗДЫ ИЗ ПОГРЕБЕНИЯ САРМАТСКОГО ВСАДНИКА ИЗ МОГИЛЬНИКА КОВАЛЁВКА}

\author{
Валерий Михайлович Клепиков \\ Волгоградский государственный университет, г. Волгоград, Российская Федерация \\ Михаил Васильевич Кривошеев \\ Волгоградский государственный университет, г. Волгоград, Российская Федерация
}


Аннотация. В статье публикуются и анализируются материалы, полученные в результате исследования кургана у с. Ковалёвка в южной части Волго-Донского междуречья. Курган 13 является частью курганного могильника, погребения которого выглядят относительно одновременными и могут быть интерпретированы как кладбище кочевников-мигрантов, закрепившихся на данной территории в противостоянии с другими сарматскими группировками. Особое внимание уделяется деталям конской узды и прежде всего удилам и псалиям, а также бляхам, украшавшим ремни оголовья. Тип стержневых псалиев с двумя прямоугольными петлями для крепления повода в центральной части и дисковидными окончаниями на концах получил распространение в сарматской среде с рубежа эр. Псалии и бляхи были декорированы аппликациями из золотой фольги. Анализ таких уздечных наборов позволил прийти к выводам, что они принадлежали профессиональным воинам-всадникам нерядового статуса. Подобные погребения известны в Нижнем и Среднем Поволжье, Нижнем, Среднем и Верхнем Подонье, на Кубани и в Крыму. Истоки традиции изготовления и использования удил и псалиев такого типа авторы находят на востоке, в районах Забайкалья, Тувы, Алтая и Северного Китая. Появление подобных погребений совпадает по времени с процессом смены сарматских культур на рубеже эр. Вероятно, воины-всадники были активными участниками этих исторических изменений. Однако определить их как этнос и даже представителей единой археологической культуры не получается. Поэтому авторы предложили видеть в таких всадниках представителей межплеменной аристократической военной группировки. Вклад авторов. М.В. Кривошеевым были проведены работы по описанию археологического комплекса, подготовка иллюстративного материала. В.М. Клепиковым выполнена аналитическая часть работы. Поиск аналогий выполнялся совместно авторами работы.

Ключевые слова. Волго-Донское междуречье, конская узда, удила, псалии, фалары, конный воин.

Цитирование. Клепиков В. М., Кривошеев М. В. Детали конской узды из погребения сарматского всадника из могильника Ковалёвка // Вестник Волгоградского государственного университета. Серия 4, История. Регионоведение. Международные отношения. -2020. - Т. 25, № 4. - C. 181-199. - DOI: https://doi.org/10.15688/ jvolsu4.2020.4.12

Введение. В 2017 г. в южной части Волго-Донского междуречья, на левом берегу реки Есауловский Аксай в Октябрьском районе Волгоградской области, был исследован курган 13 могильника Ковалёвка, в котором обнаружено погребение воина-всадника. Курган является частью курганного могильника. Его погребения выглядят относительно одновременными и интерпретируются как кладбище кочевников, закрепившихся на данной территории в противостоянии с другими сарматскими группировками. Об этом свидетельствует, с одной стороны, ряд инноваций, нехарактерных для сарматских погребений этой территории, таких как наличие костей лошади в насыпи и заполнении могил, предметов конской узды и наконечников копий, с другой - ритуальное осквернение погребений пришельцев, выразившееся в частичном разрушении могил вскоре после захоронений. Анализ сарматских погребений могильника позволил определить хронологические позиции в пределах I в. до н.э. - I в. н.э., то есть рубежным периодом между ранне- и среднесарматской культурами $[17$, с. 35-46]. Настоящая статья посвящена анализу предметов конской узды из погребения 2 кургана 13.
Материалы и методы. Курганный могильник Ковалёвка располагается в 4 км к ВЮВ от с. Ковалёвка Октябрьского района Волгоградской области. Курган 13 находился в северной части могильника. Его современная высота составляла 0,3 м, диаметр - 28 м. Насыпь была сильно распахана (рис. 1, 1).

В профилях бровок насыпи кургана фрагментарно фиксировались разрозненные грунтовые блоки, состоящие из верхнего гумусового горизонта А и части горизонта В1 луговых и осолонцеватых почв, представленных в погребенной почве данного кургана. Вероятно, курган сооружался в условиях высокой увлажненности почв, при которой возможна нарезка грунтовых блоков. Грунтовые блоки вырезались на площадке в центральной части подкурганного пространства на расстоянии от 3 до 5 м от ЦР.

В насыпи кургана встречены разрозненные кости МРС, КРС, лошади, чешуя рыбы и фрагменты керамики.

В центре кургана обнаружена нарушенная могильная яма, имевшая по верху округлые очертания. В нее было впущено погребение 1, принадлежавшее пожилой женщине, уложенной вытянуто на спине и ориентированной 
головой к западу. Вероятно, данное захоронение относится к эпохе средневековья.

Ниже располагалось основное погребение 2, над которым и была возведена курганная насыпь (рис. 1, 2). В заполнении могилы были обнаружены разрозненные кости человека, захороненного в погребении 2: череп, лучевая кость предплечья правой руки, берцовая кость левой ноги и позвонок. Под черепом человека отмечены следы желтого минерала (ярозит?).

Ко дну могильная яма погребения 2 приобрела реальные очертания. Она имела вытянутую прямоугольную форму. Длинной осью была ориентирована по линии СС3-ЮЮВ. Длина могильной ямы по дну - 2,47 м, ширина -1 м, глубина $-1,88-1,91$ м ${ }^{1}$.

В южной торцевой стенке ямы сохранился небольшой подбой шириной 0,08 м и высотой около 0,4 м. На дне in situ лежал скелет взрослого мужчины (30-40 лет). Погребенный был уложен вытянуто на спине и ориентирован к югу. Руки положены вдоль туловища, ноги вытянуты. У костяка отсутствовали череп, кости правого предплечья, берцовые кости левой ноги, кости стоп.

Между правой плечевой костью погребенного и восточной стенкой ямы на дне обнаружены фаланги пальцев человека, лежащие двумя линиями.

По всей площади ямы зафиксированы следы органической подстилки черного цвета:

1. В заполнении могильной ямы, в центральной части, на глубине 1 м, найдены осколки раковины речного моллюска. Размеры фрагментов: $3,7 \times 3 \mathrm{~cm}, 2,1 \times 1,2 \mathrm{~cm}$.

2. В заполнении могильной ямы, на глубине 1,15 м, обнаружены два фрагмента трубчатой кости крупного копытного и зуб лошади.

3. В заполнении на глубине 1,39 м найден фрагмент венчика со сливом крупного сероглиняного сосуда. Венчик отогнут наружу, под ним глубокая каннелюра. На фрагменте фиксируются два сквозных ремонтных отверстия диаметром 0,3 см. Черепок в изломе серого цвета, тесто хорошо отмучено с включениями мелкого песка. Размеры фрагмента $-9,4 \times 4,1$ см. Реконструируемый диаметр венчика -13 см (рис. 1, 8).

4. Фрагменты стенки и дна сероглиняного гончарного сосуда северокавказского про- изводства обнаружены в заполнении, на глубине 1,38 м. На стенке орнамент в виде двух горизонтальных продавленных неглубоких линий сверху и трех снизу, между ними наклонные двойные разнонаправленные линии. Черепок в изломе однородного серого цвета с включениями черного песка и слюды. Размеры фрагмента стенки $-8 \times 4,5 \mathrm{~cm}$, толщина стенки - 0,6 см. Размеры фрагмента дна $8,1 \times 5,6$. Реконструируемый диаметр дна $10 \mathrm{~cm}$, толщина - 0,35-0,45 см (рис. 1, 7).

5. На той же глубине в центральной части ямы обнаружена фаланга ноги КРС.

Находки на дне ямы:

6. Между правым крылом таза и ребрами погребенного обнаружена серебряная (?) кольцевая пряжка с неподвижным язычкомвыступом. Диаметр кольца - 3,8 см, диаметр сечения прута $-0,4$ см. Высота язычка-выступа $-0,5$ см (рис. 1, 5).

7. На поясе погребенного найдена железная пряжка с прямоугольной рамкой и длинным подвижным язычком. Длина рамки 5 см, ширина - 3,2 см. Сечение прута рамки прямоугольное - 0,5 × 0,3 см, язычок прямой, длина $-5,5$ см, в сечении прямоугольный $0,5 \times 0,4$ см (рис. 1,4$)$.

8. На костях левого предплечья и под левым крылом таза обнаружен пучок из 69 железных черешковых трехлопастных стрел. Длина наконечников 2,2-2,5 см, длина черешков 1-2,9 см. Стрелы были обращены остриями к югу и, вероятно, представляли единый колчанный набор (рис. 1, 3).

9. Вдоль правого бедра на дне могильной ямы сохранились окислы от железного кинжала (?), предположительно, с прямым перекрестием в деревянных ножнах, покрытых красной краской. Перекрестие находилось на уровне головки правой бедренной кости. Острием обращен к северу. Точно установить размеры и форму предмета не представляется возможным.

10. Между правой ногой погребенного и восточной стенкой ямы на дне лежали кости передней ноги МРС с лопаткой в сочленении, вытянуто вдоль костяка, лопаткой в сторону стоп погребенного.

11. Рядом обнаружены сильно корродированные фрагменты железного ножа (рис. 1, б).

12. Между правыми берцовыми костями погребенного и восточной стенкой ямы, на 
дне обнаружены сильно корродированные железные предметы. После реставрации ${ }^{2}$ установлено, что они представляют собой детали конской узды (рис. 2, 3).

Двусоставные удила (рис. 2, 1; 3, 1) состоят из двух звеньев-грызл, заканчивающихся петлями. Концы грызл, закругляясь в петлю, не смыкаются. Длина грызл - 9,2 см и 8,3 см. Диаметр внутренних петель грызл 2,2 см и 2,3 см. Диаметр внешних петель 3,1 см. Сечение стрежней грызл в средней части квадратное - 0,6 × 0,6 cм.

2 стержневидных псалия (рис. 2, 1; $3,1)$. Длина псалиев - 13,5 см и 13,3 см. Их стержни прямоугольные в сечении. На каждом псалии, в центральной части симметрично на расстоянии 2,6 см друг от друга, располагается пара выступающих с лицевой стороны прямоугольных рамок высотой $1,1-$ 1,3 см, с горизонтальными сквозными прямоугольными отверстиями размерами $0,8 \times$ 0,5 см. Сечение прута между выступамирамками квадратное $1 \times 1$ см. Псалии имеют плоские дисковидные окончания. Диаметр окончаний $-2,8$ см.

Лицевая сторона каждого псалия была украшена частично сохранившейся аппликацией золотой фольгой. На каждом псалии между выступами-рамками и дисковидными окончаниями были по 3 расположенных поперечно прямоугольника аппликации шириной по 0,1 см, длиной по 0,6 см. На каждом из выступов-рамок остались лишь тонкие следы крепления аппликации к железной основе. Аппликация представляла собой по два поперечных золотых прямоугольника длиной по 0,5 cм, шириной по $0,25 \mathrm{~cm}$.

Дисковидные окончания псалиев также апплицированы золотой фольгой, образующей орнамент, повторяющийся на каждом из окончаний: по внешнему краю диска располагается кольцо золотой фольги шириной 0,2 см. Диаметр кольца - около 2,7 cм, немного меньше общего диаметра диска. Внутри внешнего кольца располагается кольцевой орнамент, состоящий из примыкающих боковыми сторонам трапеций из золотой фольги, обращенных вершинами к центру. В центре орнамента располагается круг из золотой фольги диаметром около $1 \mathrm{~cm}$. Все детали орнамента разделены свободным пространством шириной 0,1 см.
В одну из внешних петель грызл вставлено дополнительное кольцо размерами $2,5 \times 2,8 \mathrm{~cm}$. Кольцо в сечении прямоугольное - 0,3 × 0,4 cм. На внешней петле второго грызла фиксируется прикипевший фрагмент второго дополнительного кольца. Его длина - 2 см, сечение - круглое диаметром 0,2 см.

5 крупных блях (рис. 2, 1; 3, 2). Представляют собой диски диаметром от 2,6 до $3 \mathrm{~cm}$, толщиной до $0,25 \mathrm{~cm}$. Орнамент золотой аппликацией на крупных бляхах повторяет орнамент окончаний псалиев (рис. 2, 2a).

С оборотной стороны каждой бляхи находились П-образные железные петли с расходящимися наружу концами, припаянными к железному основанию блях бронзовым припоем (следы окислов бронзы в месте креплений). Петли сохранились не на всех бляхах. Они сделаны из уплощенного стрежня шириной 0,4 см. Высота петель - 1,2 см.

3 мальих бляхи (рис. 2, 1; 3, 3). Представляют собой диски диаметром $1,7-1,75$ см, толщиной до 0,1 см. Лицевая сторона блях апплицирована золотом (рис. 2, 2б). Орнамент состоит из внешнего кольца золотой фольги шириной 0,1 см. Диаметр кольца соответствует диаметру самой бляхи. Внутри внешнего кольца располагается орнамент, состоящий из 8 золотых сегментов, образованных рассеченными линиями незаполненного пространства шириной до $0,1 \mathrm{~cm}$ - одной продольной и тремя перпендикулярными. Все детали орнамента разделены свободным пространством шириной до $0,1 \mathrm{~cm}$.

С оборотной стороны каждой бляхи зафиксированы частично сохранившиеся основания петель для крепления к ремням уздечки (ширина - 0,68 см), припаянные к основанию бляхи бронзовым припоем. Вероятно, крепления представляли собой обоймы с несомкнутыми верхними концами для крепления к ремню.

2 наконечника ремней (?) (рис. 2,$1 ; 3,5)-$ железные пластины размерами $3,6 \times 1$ см и $3 \times 0,9$ см. Толщина пластин - до 0,2 см. В их верхней части с обратной стороны фиксируются корродированные элементы креплений. К верхней части одной из пластин прикипел фрагмент плоского железного кольца диаметром $2 \mathrm{~cm}$, в сечении $0,27 \times 0,1$ см. Лицевая сторона фрагмента кольца была апплицирована золотой фольгой. 
Лицевая сторона обеих железных пластин наконечников апплицирована пятью поперечно расположенными пластинками золотой фольги (рис. 2, 26). Размеры нижней золотой пластинки 0,7 × 0,28 см. Каждая последующая, отстоящая на 0,1 см, уменьшается.

Деталь украшения узды (рис. 2, 1; рис. 3,4$)$. Представляет собой железную зигзагообразную уплощенную пластину шириной 0,7 см и толщиной $0,18-0,2 \mathrm{~cm}$. На одном из концов пластины расположена округлая бляха диаметром 1,8 см. Нижний край изделия и часть пластины обломаны. Общая длина изделия - 5,3 см.

С обратной стороны дисковидного окончания фиксируется частично сохранившееся основание петли для крепления к ремню уздечки. Ширина основания крепления $-0,42$ см. Оно припаяно к основанию бляхи бронзовым припоем. На оборотной части пластины, примыкающей к дисковидному окончанию, сохранились корродированные детали петли крепления. Ширина петли $-0,95$ см.

Лицевая часть пластины украшена орнаментом из фольги желтого (золота) и белого металла в виде двух параллельных полосок на каждом из колен пластины. Дисковидное завершение изделия украшено орнаментом из золотой фольги, повторяющим орнамент на малых бляхах.

В процессе реставрационных работ были отмечены особенности техники апплицирования золотой фольгой псалиев и деталей уздечного набора. На железной основе изделий режущим инструментом делались прорези в соответствии с предполагаемыми контурами орнамента. Затем на деталь накладывался целый лист золотой фольги. Вероятно, между ними наносился клей. Отдельные участки фольги запрессовывались в существующие прорези на железной поверхности изделия. После этого некоторые части золотой фольги вырезались, что создавало контрастный рисунок золотой и железной поверхности. В настоящем виде многие части золотой аппликации утрачены, но запрессованные контуры золотой фольги сохранились в прорезях железной основы (рис. 2, 3). Это позволяет полностью реконструировать орнаментальные особенности рассматриваемого уздечного набора ${ }^{3}$.
В процессе реставрации уздечного набора в изломе одного из псалиев были обнаружены включения мелких фрагментов золота (рис. 2, 22). Это может свидетельствовать о вторичном использовании железа, из которого изготовлены псалии.

Изучение представленного материала предполагает применение как традиционных общенаучных методов, включая хронологический и пространственный анализ, так и специальнонаучные методы археологического исследования, включая формально-типологический, картографический и метод аналогий, применяемые и для описания научных фактов, и для реконструкции динамики этнокультурных процессов.

Анализ. Атрибуция погребения в кургане 13 могильника Ковалёвка в кругу одновременных комплексов уже была предложена в недавней публикации (см.: [17, с. 38, 40]), однако видится важным подробнее остановиться на деталях конской узды. Уздечный набор представлен удилами с псалиями, пятью относительно крупными и тремя малыми плоскими бляхами оголовья, декорированными золотой аппликацией, с креплениями на тыльной стороне. Подобные двусоставные удила с трензельными кольцами традиционны для сарматского уздечного набора, универсальны и бытовали достаточно долго. А вот различные типы псалиев дают возможность уточнить ареал, время и, вероятно, пути их распространения.

В типологии псалиев обычно учитывается форма основы, позволяющая разделить их на С-видные, кольцевидные, очковидные, колесовидные, крестовидные (насадки) и стержневые. Варианты определяются материалом изготовления и особенностями элементов крепления, а декоративное оформление верхнего и нижнего окончаний оценивается в лучшем случае на уровне подвариантов либо описывается как индивидуальный элемент $[1$, с. 84-94; 22 , c. $168-170 ; 35$, с. 161-166].

В нашем случае представлены штыревые псалии с прямоугольными выступающими петлями и дисками на концах, с орнаментом, повторяющимся на крупных бляхах этого же набора.

Такие псалии с двумя прямоугольными выступающими петлями для крепления ремней оголовья и дисковидными окончаниями 
хорошо известны в погребениях среднесарматской знати Нижнего Поволжья и Подонья.

Недалеко от с. Ковалёвка также на первой надпойменной террасе левого берега реки Есауловский Аксай у пос. Октябрьский в богатом среднесарматском погребении найдено пять комплектов удил и псалиев того же типа. Отличия заключались лишь в оформлении окончаний псалиев, которые были представлены вариантами листовидной и стреловидной формы в виде раскованных лезвий и дважды - колечек с выступами. Два комплекта было инкрустировано золотой фольгой. Погребение датировано авторами I в. н.э. [28, с. 151-153, 156, рис. 5]. Однако В.И. Мордвинцевой не исключался хронологический диапазон комплекса с I в. до н.э. по первую половину I в. н.э. [26, с. 65-66]. Там же, в 3 км от пос. Октябрьский на правом берегу реки Есауловский Аксай у с. Жутово, в тайнике богатого среднесарматского погребения из кургана 28 обнаружены двусоставные удила и псалии с прямоугольными двойными петлями и дисковидными окончаниями, выкованные из квадратного в сечении прута, плакированные золотыми бляхами, аналогичными фаларам оголовья. Погребение датировано первой половиной I в. н.э. [25, с. 42 , рис. $1 ; 41$, с. 60,62$]$. К югу от указанных памятников бассейна Есауловского Аксая, в Калмыкии, в богатом впускном воинском погребении у пос. Яшкуль известна еще одна полная аналогия уздечному набору из Ковалёвки (рис. 4, 2) [30, с. 1012 , рис. 7]. В дискуссии, разгоревшейся по поводу датировки этого погребения, предлагались различные хронологические позиции: до рубежа эр [26, с. 76; 36, с. 21-22], начальный этап среднесарматской культуры [5, с.102], вторая половина I в. н.э. [30, с. 38].

Особенно много аналогичных уздечных наборов встречается на Нижнем Дону. В могильнике Царский, рядом с древним Танаисом, в ограбленном среднесарматском погребении найдены уздечные бляхи и двучленные удила со стержневыми двухпетельчатыми псалиями, оканчивающимися несомкнутыми кольцами тамгообразной формы. Псалии инкрустированы поперечными золотыми брусочками, бляхи - золотой фольгой. М.В. Власкин датировал погребение второй половиной I - началом II в. н.э. [3, с. $67-68$, рис. 1,1$]$.
В сарматских погребениях сальско-манычской степи в могильнике у х. Новый в среднем течении реки Сал также обнаружена целая серия удил, псалиев и уздечных блях, инкрустированных золотой, серебряной и даже бронзовой фольгой. Предложив раннесарматскую атрибуцию этих погребений по особенностям погребального обряда, Л.С. Ильюков и М.В. Власкин приходят к выводу, что сопутствующий инвентарь свидетельствует о сохранении раннесарматских традиций не только до рубежа эр, но и в начале I в. н.э. [15, с. 230 , рис. 20,$1 ; 22,1 ; 25,2-4 ; 26,7 ; 30,16]$. В дальнейшем хронологический анализ вещевого материала позволил развить это наблюдение, определив исследуемые комплексы как раннесарматские, сохранившие свои погребальные традиции в среднесарматское время и в среднесарматском окружении $[4$, c. $61-$ $62 ; 33$, с. 149].

В этом же ряду предметов конской узды можно упомянуть псалии парадного уздечного набора из тайника среднесарматского кургана Дачи второй половины І в. н.э., с прямоугольными петлями и концами, раскованными в виде округлой площадки, на которых закреплялись золотые овальные фалары [2, с. 210, 212 , рис. 114]. Аналогичный уздечный набор обнаружен в богатом женском погребении из кургана 10 Кобяковского могильника, датированном концом I - первой половиной II в. н.э. Особенностью этих стержневидных псалиев с дисковидными окончаниями и накладными бляхами было двудырчатое восьмерковидное утолщение посередине вместо прямоугольных выступающих петель. В.К. Гугуев, отмечая довольно скромный облик сбруи на фоне массивных и высокохудожественных украшений погребенной, высказал предположение о второстепенной роли этого элемента для погребенной женщины в отличие от статусных мужских погребений, хотя само наличие упряжи должно было подчеркивать высокий статус сарматки [8, с. 101-112, рис. 1-3].

С рубежа эр рассматриваемый тип удил и псалиев получил распространение далее на запад в Северном Причерноморье, особенно в Крыму [1, с. $90-95$, рис. 3 ; 13, с. 103 , рис. 8 , $5 ; 40$, рис. 2,1$]$. Стержневидные псалии с прямоугольными выступающими петлями и окончаниями тамгообразной формы, плакирован- 
ные золотой фольгой, отмечены среди древностей Зубовско-Воздвиженской группы и «Золотого кладбища» на Кубани, датированных рубежом эр и второй половиной I - II в. н.э., причем большая часть погребений не выходит за пределы первой половины II в. н.э. [10, c. 88 , табл. V, $48, \mathrm{XI}, 125 ; 11$, с. 37 , табл. 49 , $472,56,555]$.

Заметим, что кроме западного направления, распространение такого типа конской сбруи прослеживается на север, в лесостепные районы. В северной части междуречья Волги и Дона, на севере Волгоградской области в районе, пограничном с лесостепью, у с. Нижняя Добринка Жирновского района исследовано ограбленное погребение, принадлежащее к кругу сарматской знати, датированное авторами публикации второй половиной I - началом II в. н.э. Среди сохранившихся предметов погребального инвентаря обнаружены и двусоставные удила в комплекте со стержневидными псалиями, имевшими двойные прямоугольные петли для крепления ремней оголовья и кольца на концах стержней с отходящими наружу отростками. Псалии инкрустированы серебряной проволокой [34, с. 117, рис. 3].

В лесостепной зоне Среднего Подонья в низовьях реки Воронеж в воинских погребениях I Чертовицкого могильника (курганы 6/11 и 19/19) второй половины I - начала II в. н.э. вместе с двусоставными удилами вновь обнаруживаются стержневидные квадратные в сечении псалии с двумя прямоугольными петлями, но без декоративных оформлений на концах $[23$, с. 63 , рис. 12,$4 ; 19,2]$.

В лесостепи Верхнего Подонья на правом берегу реки Красная Меча у с. Вязово Тульской области в погребении кургана 37 найдены удила со стержневыми двудырчатыми псалиями, концы которых завершались дисками, плакированными золотой фольгой. Погребение датировано II - первой половиной III в. $[24$, с. 87 , рис. $74,76,12]$. Восточнее Вязовского могильника на правом берегу реки Дон в Липецкой области в погребении этого же времени из кургана 29 Ново-Никольского могильника обнаружены двусоставные удила со стержневыми псалиями, имевшими по две прямоугольные петли для ремней оголовья [ 24 с. 87 , рис. $70,1-10,76,11]$.
В лесостепном правобережье Среднего Поволжья на границе леса и лесостепи в зоне контактов местного и пришлого кочевого населения в погребениях Андреевского кургана, Писеральского курганного могильника и ряда других известны те же типы удил и псалиев, инкрустированные золотой и бронзовой фольгой и датированные серединой I - началом II вв. н.э. [7, с. 90-91, рис. 22, 5-8; 14, рис. $7,4,6]$.

Подчеркнем, что практически все погребения с удилами и псалиями этого типа обнаружены вместе с оружием в погребениях воинов отнюдь не рядового статуса. Следует выделить и еще одну особенность погребального обряда - в большинстве таких погребений в качестве напутственной пищи найдены кости лошади, иногда упоминаются кости крупных домашних животных без определений [7, c. $37 ; 11$, c. $8 ; 15$, с. $80,114,115,227 ; 17$, c. 40 ; 24$, c. 56,57$]$.

Стоит отметить важный момент: датировка подобных погребений нередко приходится на рубеж эр и совпадает с периодом смены раннесарматской на среднесарматскую культуру. Либо они датируются шире - среднесарматским временем. Причем если в волго-донском регионе даже возникает сложность с определением культурной принадлежности комплексов на стыке культур, то на северных рубежах такие памятники появляются на полстолетия позже, что позволяет проследить динамику процесса.

Отмечая однотипность псалиев, исследователи обращаются к общему кругу аналогий. При этом поиски исходных территорий приводят к хронологически более ранним либо одновременным восточным аналогиям [8, c. $111 ; 28$, с. $156 ; 30$, с. $32 ; 34$, с. 122$]$.

В частности, в комплектах конской узды из хуннских погребений 46 и 50 могильника Ильмовая падь в ЮЗ Забайкалье, датируемых I в. до н.э. - I в. н.э., присутствуют стержневые псалии с двумя прямоугольными петлями $[18$, с. 35,50 , табл. VI, 1]. Дисковидные окончания деревянных псалиев Пазырыка и прямоугольные петли на деревянных псалиях Уландрыка позволили М.А. Очир-Горяевой связать сарматские псалии с культурой Горного Алтая [30, с. 32]. Причем традиция скифского времени украшать концы костяных пса- 
лиев дисковидными уплощениями сохранилась и в хуннуских памятниках II в. до н.э. - I в. н.э. на Алтае для железных стержневидных псалиев [38, с. 34 , рис. 1,42$]$.

Продолжить перечень аналогий позволяют опубликованные памятники из Средней Азии, и в первую очередь хорошо известные изображения всадников на поясных пластинах Орлатского могильника [31]. Особо следует отметить стержневые псалии с дисковидными окончаниями в сцене охоты и перекрестия мечей в батальной сцене. Хотя конская сбруя отсутствует в сопутствующем инвентаре погребения из кургана 2 Орлатского могильника, наличие меча с ромбовидным перекрестием вместе со скобой из нефрита и железными черешковыми наконечниками стрел свидетельствует о прямом тождестве изображенного и погребенного оружия [29, рис. 1, 3-5]. Датировка изображений вызвала серьезную дискуссию, в результате которой хронологические позиции определяются и как конец IIІ в. до н.э. - начало н.э. [31, с. 56; 32, с. 150 $153 ; 37$, с. 151-153], и І в. до н.э. - II в. н.э. [16, с. 102-103], и I-II вв. н.э. [21, с. 229], и ІІІ в. н.э. $[19$, с. 201], и в более широком интервалепервая половина I тыс. н.э. [29, с. 143]. При всем разнообразии иконографических аргументов, следует обратить внимание на то обстоятельство, что археологическая база дискуссии во многом не соответствует современным реалиям, поскольку авторы, ссылаясь на сарматские материалы Приуралья, Поволжья и Подонья, находят аналогии лишь в среднесарматских комплексах I-II вв. н.э., фиксируя, например, наличие псалиев с дисковидными окончаниями, мечей с ромбовидными перекрестиями и ложечковидных подвесок [19, c. $193 ; 21$, с. 220-221, 226, 229]. Однако мечи этого типа хорошо известны уже в раннесарматских комплексах II-I вв. до н.э. [37, с. 96, 151-154], как и ложечковидные подвески [38, c. 204-208]. Стержневидные псалии, судя по находкам из Антиповского клада и Яшкуля, также появляются к западу от Волги не позже I в. до н.э. [24, с. 19-20; 36, с. 21-22]. Разумеется, эти датировки не отрицают бытования упомянутых категорий вещей и в III вв. н.э., но дополнительно фундируют аргументацию сторонников ранней даты орлатских изображений.
Заметим, что изображение стержневых псалиев с дисковидными окончаниями на Opлатских пластинах не единично. На пластине из слоновой кости со сценой охоты из ТахтиСангина мы находим тот же тип псалиев в уздечном наборе коня под всадником, скачущем влево [19, с. 181-184, рис. 1-3]. Показательно, что еще в одной сцене верховой охоты, изображенной на серебряном сосуде в сарматском погребении первой половины I в. н.э. из кургана 4 могильника Вербовский, расположенного на левом берегу Дона, то есть далеко на запад, вновь обнаруживается этот тип псалиев [27, рис. 12, 14, с. 89-90].

Удила с дисковидными окончаниями псалиев, инкрустированные золотой фольгой, встречены в катакомбе 1 кургана 50 Шаушукумского могильника в районе среднего течения Сыр-Дарьи. Подчеркнем, что там же, в аналогичной катакомбе из кургана 56, вместе с железными черешковыми наконечниками стрел найдены обломки железного меча с бронзовым ромбовидным перекрестием [12, c. 257,258 , табл. XX, XXII, 3$]$.

Длинные мечи с нефритовыми и бронзовыми перекрестиями и скобами для крепления ножен хорошо известны в древностях ханьского Китая, и в последние века до н.э. получили распространение в кочевом мире благодаря племенам северо-западных китайских приграничий [6, с. 37, табл. XVII, 21; 36, c. 17-24].

Восточный ареал использования стержневых псалиев с дисковидными окончаниями также можно продлить до Китая, поскольку в мавзолее Янлин, принадлежавшем императору Цзин-ди, похороненному в 141 г. до н.э., были найдены бронзовые позолоченные двусоставные удила и стержневые двудырчатые псалии, украшенные по концам дисками с умбонами (рис. 4, 1) [20, cat. 167, p. 89].

Таким образом, появление в европейской степи и лесостепи конского уздечного набора со стержневидными псалиями и прямоугольными петлями с дисковидными и иными фигурными окончаниями вместе с целым списком других восточных предметов, таких как длинные мечи с ромбовидными бронзовыми и железными перекрестиями, ажурные рамчатые пряжки, ложковидные застежки, миниатюрные копии котлов и луков с колчанами, 
колокольчики, курильницы кубической формы и другие артефакты, имеющие аналогии в памятниках Средней Азии, Тувы, Среднего Енисея, Забайкалья, Северного Китая (рис. 5, 127), - это отражение достаточно мощного миграционного процесса, начавшегося со II-I вв. до н.э. и продолжавшегося в среднесарматское время [37, с. 151-156]. Вполне возможно, что анализируемые нами уздечные наборы появились уже вместе с первой волной. Во всяком случае, наиболее ранний пример - материалы Антиповского клада, где вместе с фаларами и шлемом типа Монтефортино найдены удила и псалии, среди которых есть и стержневые с двумя прямоугольными петлями и расплющенными концами [9, с. 241-246, рис. 1-3]. Наиболее предпочтительно дата Антиповского комплекса выглядит в хронологических рамках конца II - первой половины I в. до н.э., а если согласиться с гипотезой о появлении таких кельто-италийских шлемов в сарматском доспехе в связи с участием сарматов в Митридатовых войнах первой трети І в. до н.э., то и в более узком временном диапазоне [24, с. 19-20].

Результаты. Анализ уздечных наборов, в комплекте которых присутствуют двусоставные удила и стержневидные псалии с выступающими прямоугольными петлями, позволяет предложить ряд выводов.

Во-первых, анализируемые образцы конской узды обычно обнаруживаются в погребениях воинов не рядового статуса. Сопутствующий инвентарь представлен не только мечами и наконечниками стрел, но и предметами из золота, престижной посудой, да и сами элементы узды часто плакированы золотом либо серебром. Кроме того, статус воинавсадника подчеркнут наличием костей лошади в погребении, что в целом нетрадиционно для сарматских погребений.

Во-вторых, появление такого уздечного набора можно связать с восточным миграционным влиянием конца II - I в. до н.э., однако о широком распространении можно говорить лишь с рубежа эр. Вероятно, сложный процесс смены сарматских культур нашел свое отражение и в появлении погребений конных воинов-профессионалов. Сама дискуссионность вопросов отнесения тех или иных памятников к ранне- либо среднесарматской культурам (Яш- куль, Новый, Ковалёвка), проблемы этнической атрибуции подобных комплексов на Кубани, в лесостепном Подонье и Поволжье («Золотое кладбище», Зубовско-Воздвиженская группа, I Чертовицкий, Ново-Никольский, Вязовский могильники, Андреевский курган) свидетельствуют о сложных исторических пертурбациях первых веков н.э. Иными словами, все эти вооруженные всадники выглядят эдакими воинами фронтира. Вероятно, некоторые становятся вождями крупных объединений, о чем свидетельствуют статусные погребения (Жутово, Октябрьский V, Дачи). Однако определить их этническую принадлежность и даже однозначную культурную атрибуцию в археологическом контексте не представляется возможным, поскольку такие воины-всадники оказываются погребены и в курганах-кладбищах по раннесарматским традициям, и под индивидуальной насыпью среднесарматского погребального канона. Да и сам географический разброс памятников не позволяет очертить сколько-нибудь определенную локальную территорию.

В этом случае приходит на ум весьма любопытная интерпретация термина «аланы», предложенная М.Б. Щукиным. Он высказал предположение, согласно которому ранние аланы еще не были ни народом, ни племенем, а появились в качестве межплеменной аристократической военной группировки, дружины аристократов, потомственных воинов-профессионалов, обладающих высокой выучкой и связанных родством с аристократическими домами разных кочевнических объединений. «Группа могла быть и не очень многочисленной и не очень стабильной, но весьма мобильной, постоянно ищущей применения своим силам в разных частях сарматского мира и на его границах, и подчас организующей и собственные акции» в силу чего ее невозможно локализовать [42, с. 119-121].

\section{ПРИМЕЧАНИЯ}

${ }^{1}$ Все глубины даны от 0.

2 Выражаем искреннюю благодарность за реставрационные работы реставратору Волгоградского областного краеведческого музея А.Г. Черёмушникову.

${ }^{3}$ Благодарим А.Г. Черёмушникова за предоставленную информацию. 


\section{АРХЕОЛОГИЯ РАННЕГО ЖЕЛЕЗНОГО ВЕКА}

\section{ПРИЛОЖЕНИЕ}
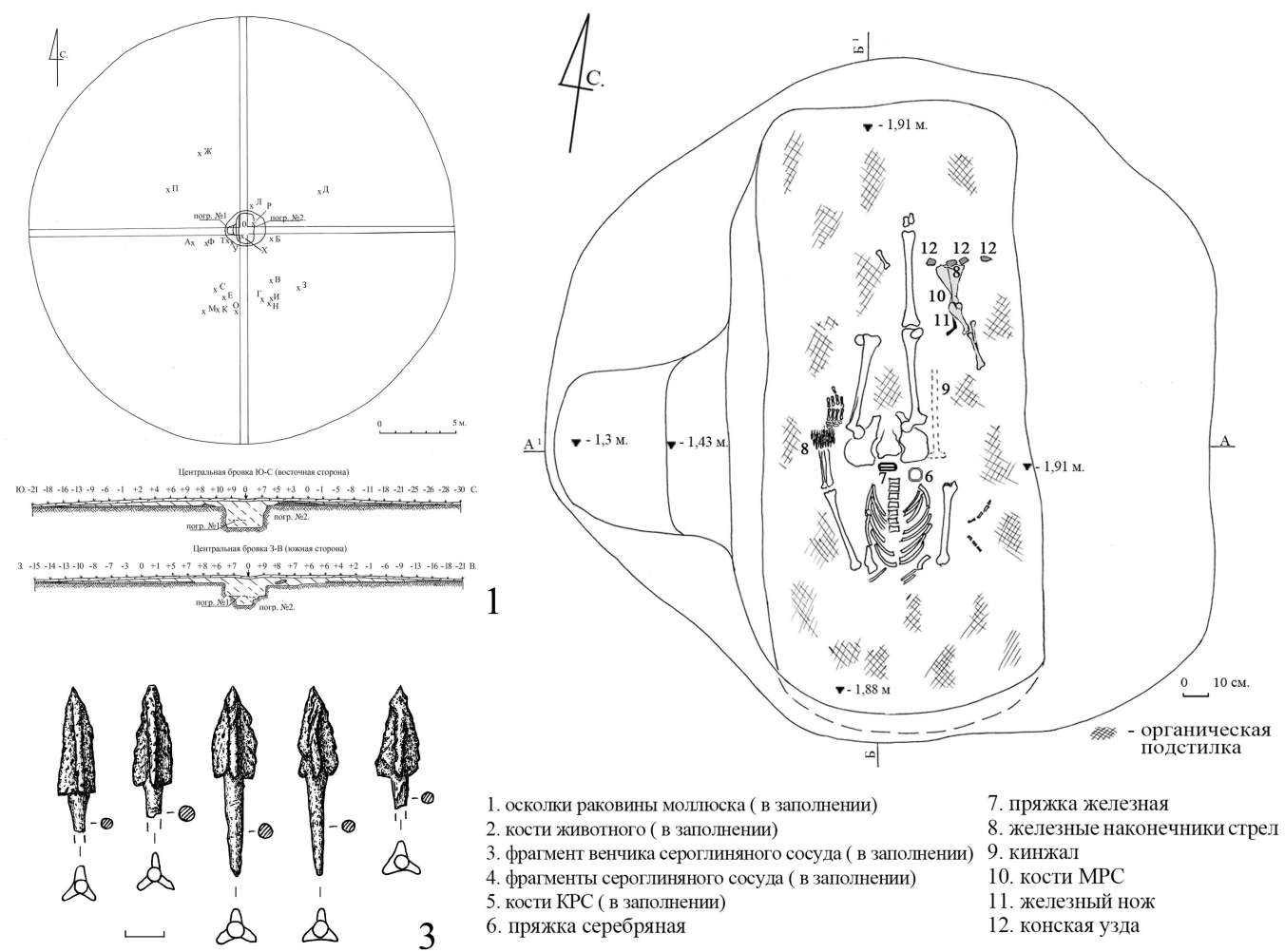

2. кости животного (в эаполнении)

4. фрагменты сероглиняного сосуда (в заполнении) 10. кости МРС

$\begin{array}{ll}\text { 5. кости КРС ( в заполнении) } & 11 . \text { железный нож }\end{array}$

3 6. пряжка серебряная

2. конская узда
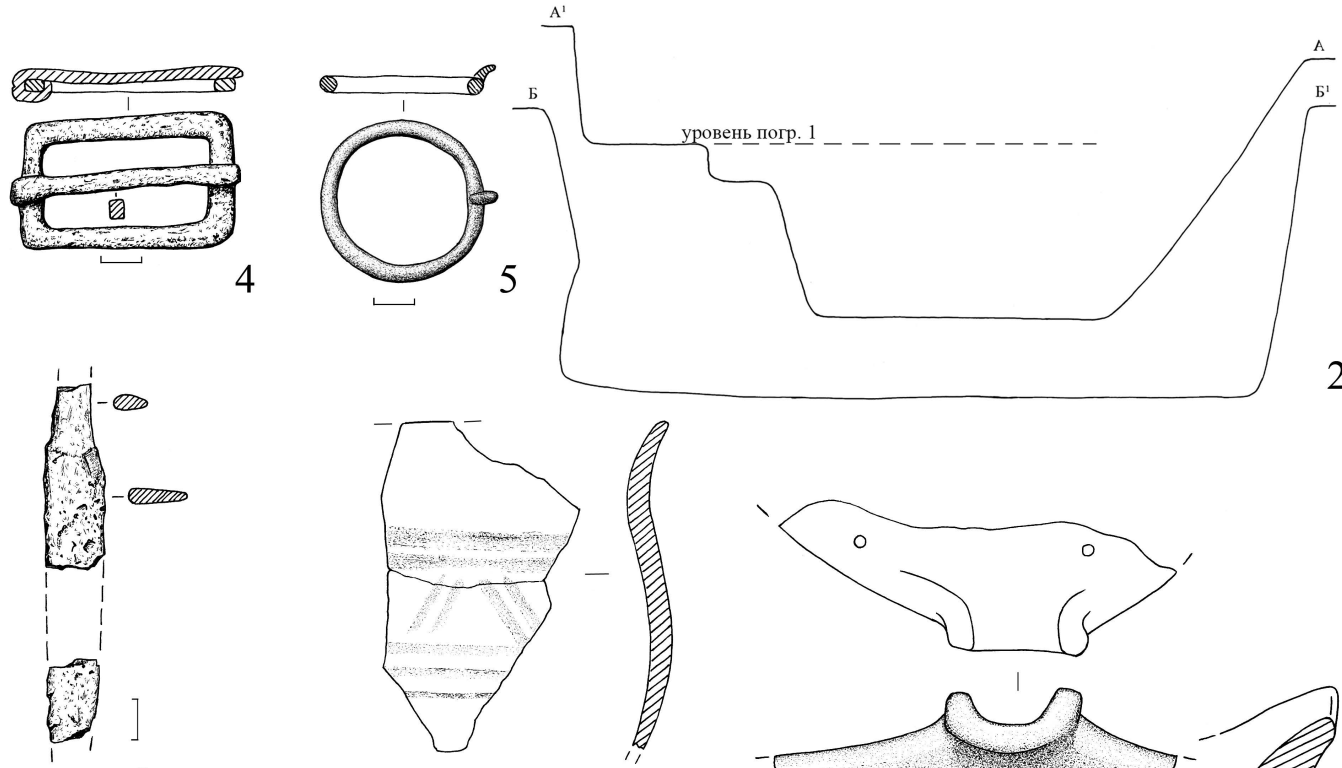

4

6
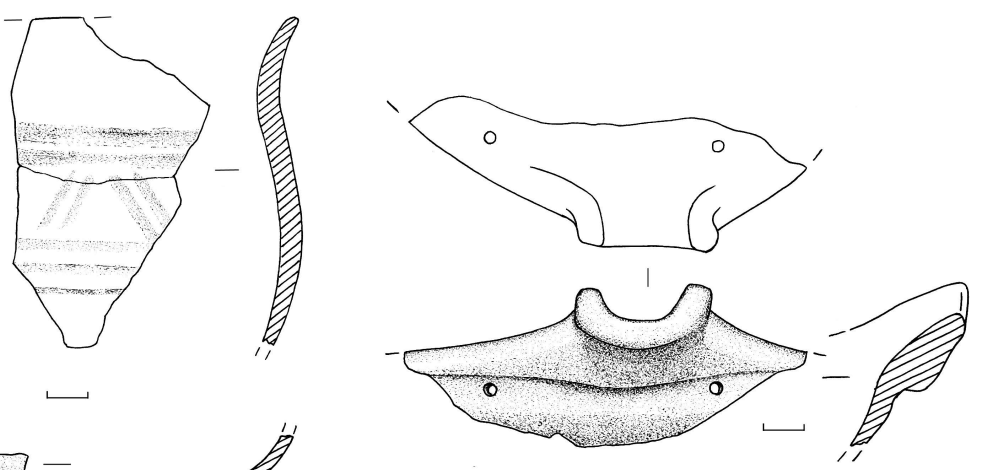

Рис. 1. Комплекс кург. 13 погр. 1 могильника Ковалёвка:

1 - план кургана; 2 - план погр. 1; 3 - железные наконечники стрел; 4 - пряжка железная; 5 - пряжка серебряная; 6 - нож железный; 7 - фрагменты гончарного сосуда; 8 - фрагмент венчика со сливом сосуда гончарного

Fig. 1. Kurgan cemetery Kovalevka, kurgan 13, burial 1:

1 - kurgan plan; 2 - plan of burial 1;3 - iron arrowheads; 4 - iron buckle; 5 - silver buckle; 6 - iron knife; 7 - ceramic vessel fragments; 8 - fragment of ceramic vessel neck ring 

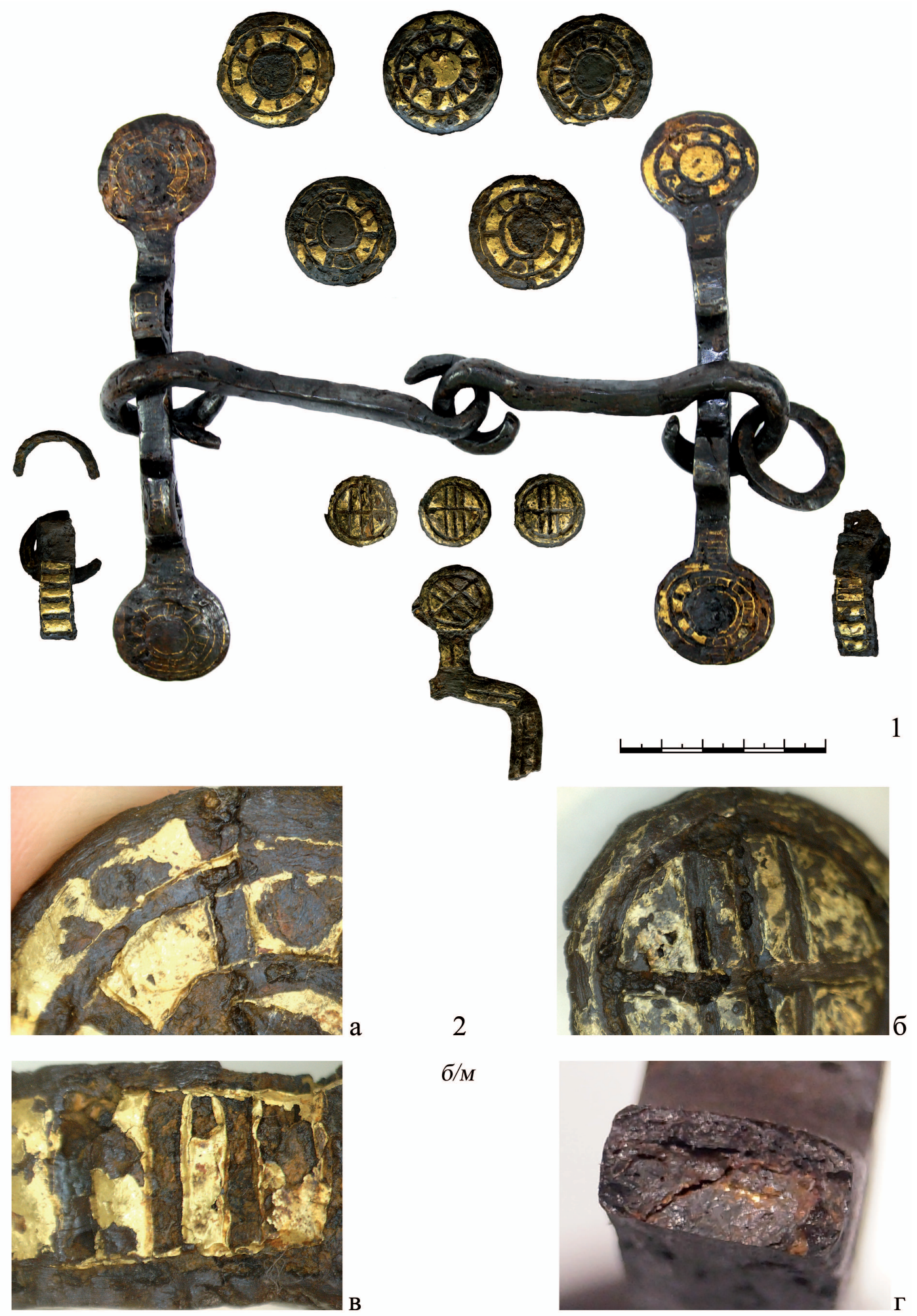

Рис. 2. Ковалёвка, кург. 13, погр. 1:

1 - конская узда; 2 - детали: $a-6$ - аппликация золотой фольгой; 2 - включения золота в изломе псалия Fig. 2. Kurgan cemetery Kovalevka, kurgan 13, burial 1:

1 - horse bridle; 2 - details: $a-6$ - gold foil applique; 2 - gold flecks in cheek-pieces fracture 

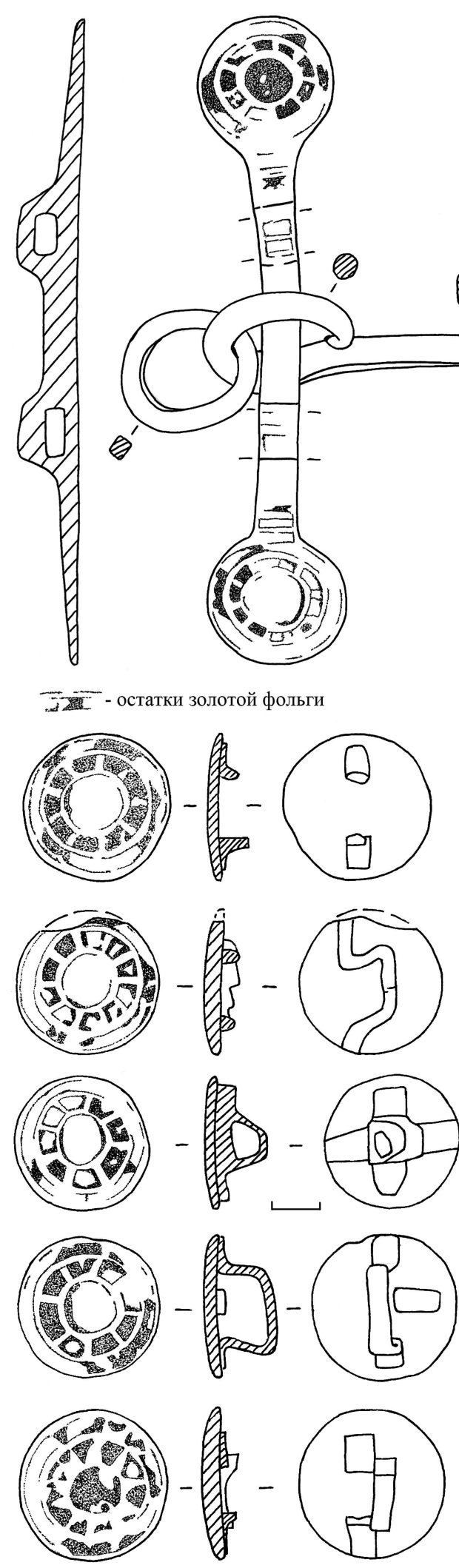
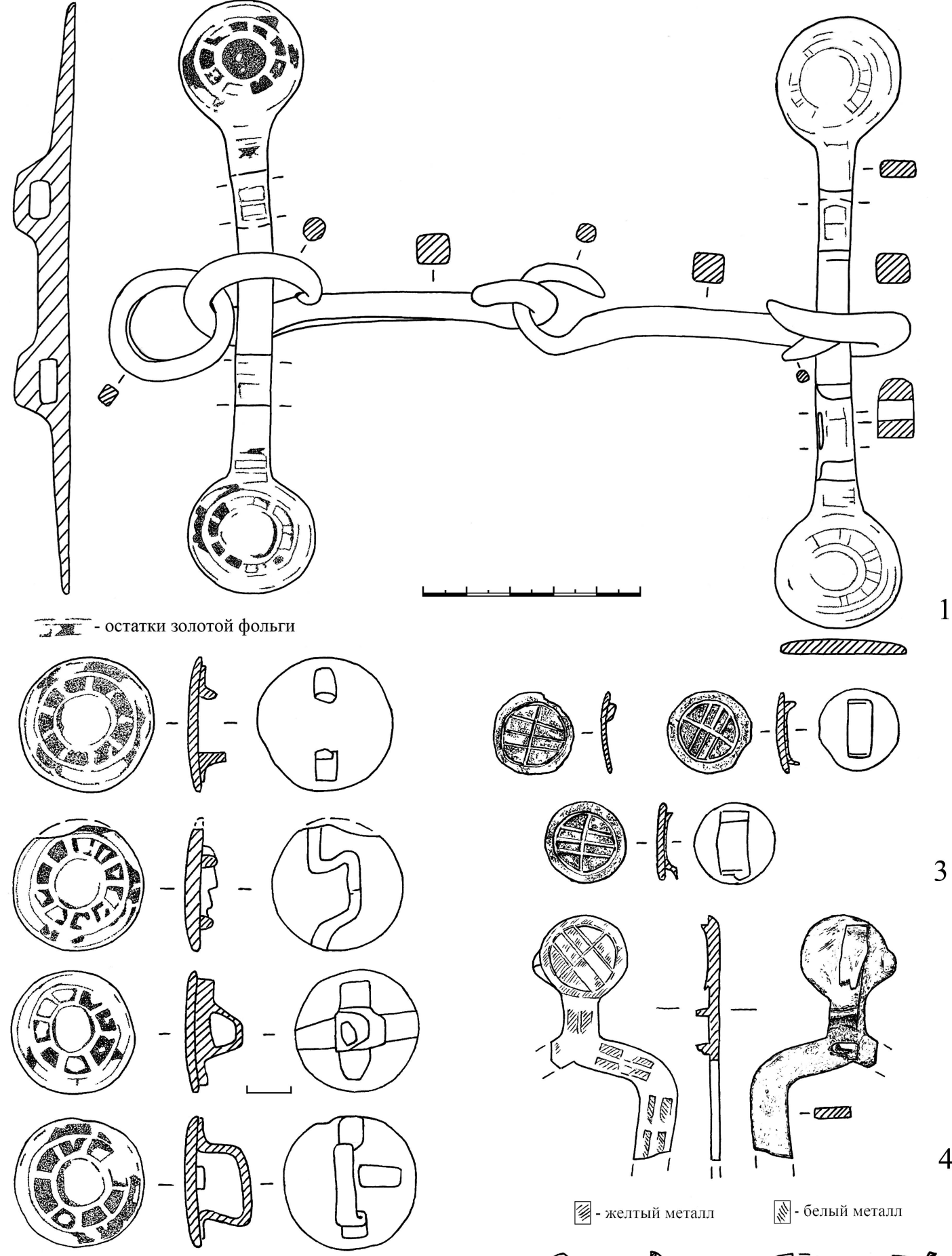

圈 - желтый металл
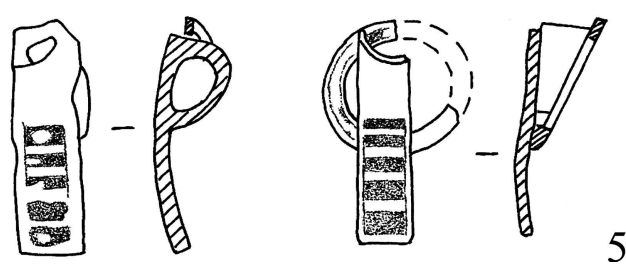

5

Рис. 3. Ковалёвка, кург. 13, погр. 1:

1 - уздечка с псалиями; 2 - крупные бляхи; 3 - малые бляхи; 4 - деталь узды; 5 - наконечники ремней Fig. 3. Kurgan cemetery Kovalevka, kurgan 13, burial 1:

1 - horse bridle with cheek-pieces; 2 - massive plaques; 3 - small plaques; 4 - bridle detail; 5 - belt buckle tips 

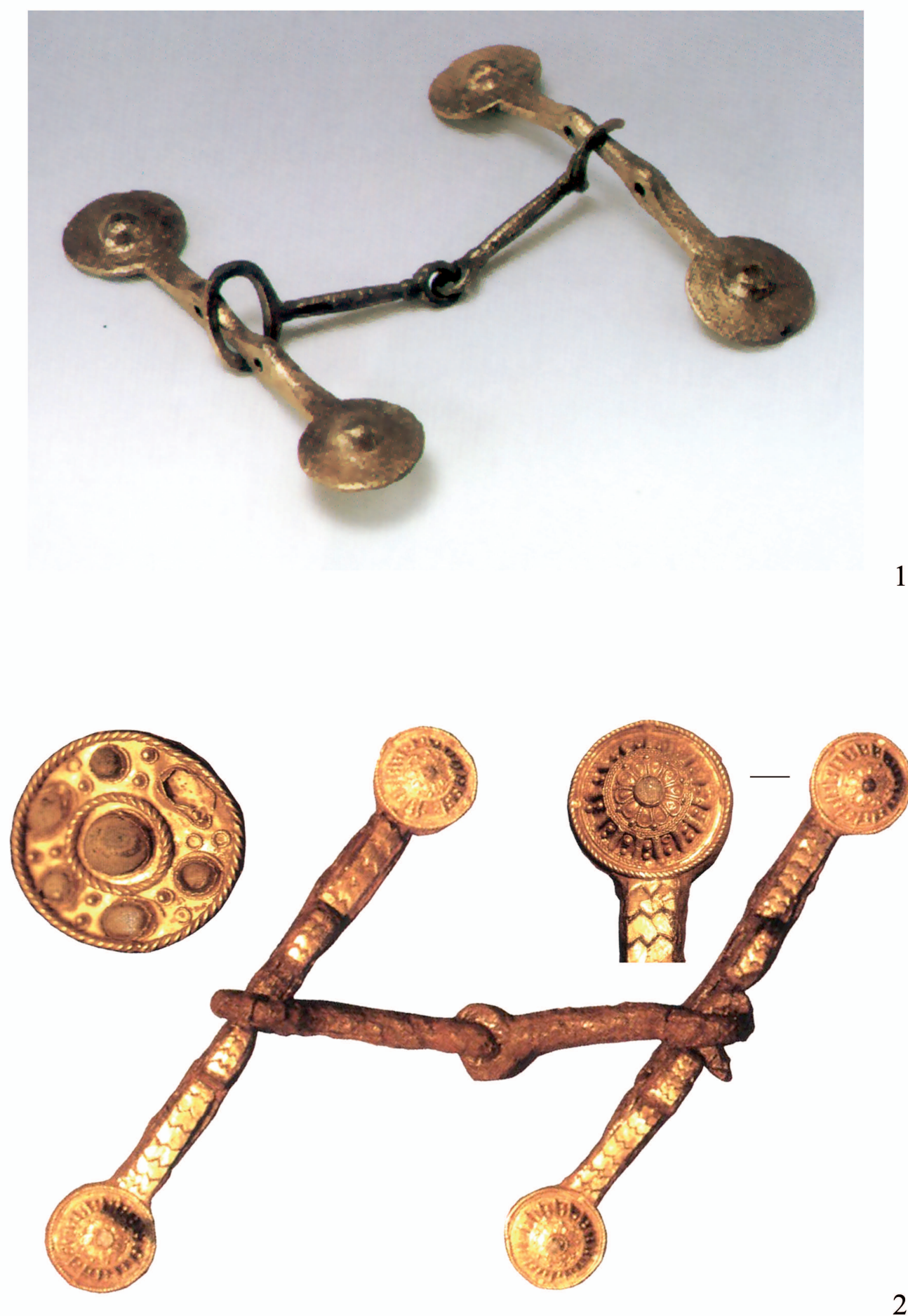

Рис. 4. Аналогичные уздечные наборы:

1 - узда из мавзолея Янлин императора Цзин-ди (Китай) [20, cat. 167, p. 89];

2 - узда из погребения у пос. Яшкуль [30, с. 10-12, рис. 7]

Fig. 4. Analogous bridle sets:

1 - horse bridle from Hanyang Mausoleum (China) [20, cat. 167, p. 89];

2 - horse bridle from burial near Yashkul [30, p. 10-12, fig. 7] 


\section{АРХЕОЛОГИЯ РАННЕГО ЖЕЛЕЗНОГО ВЕКА}

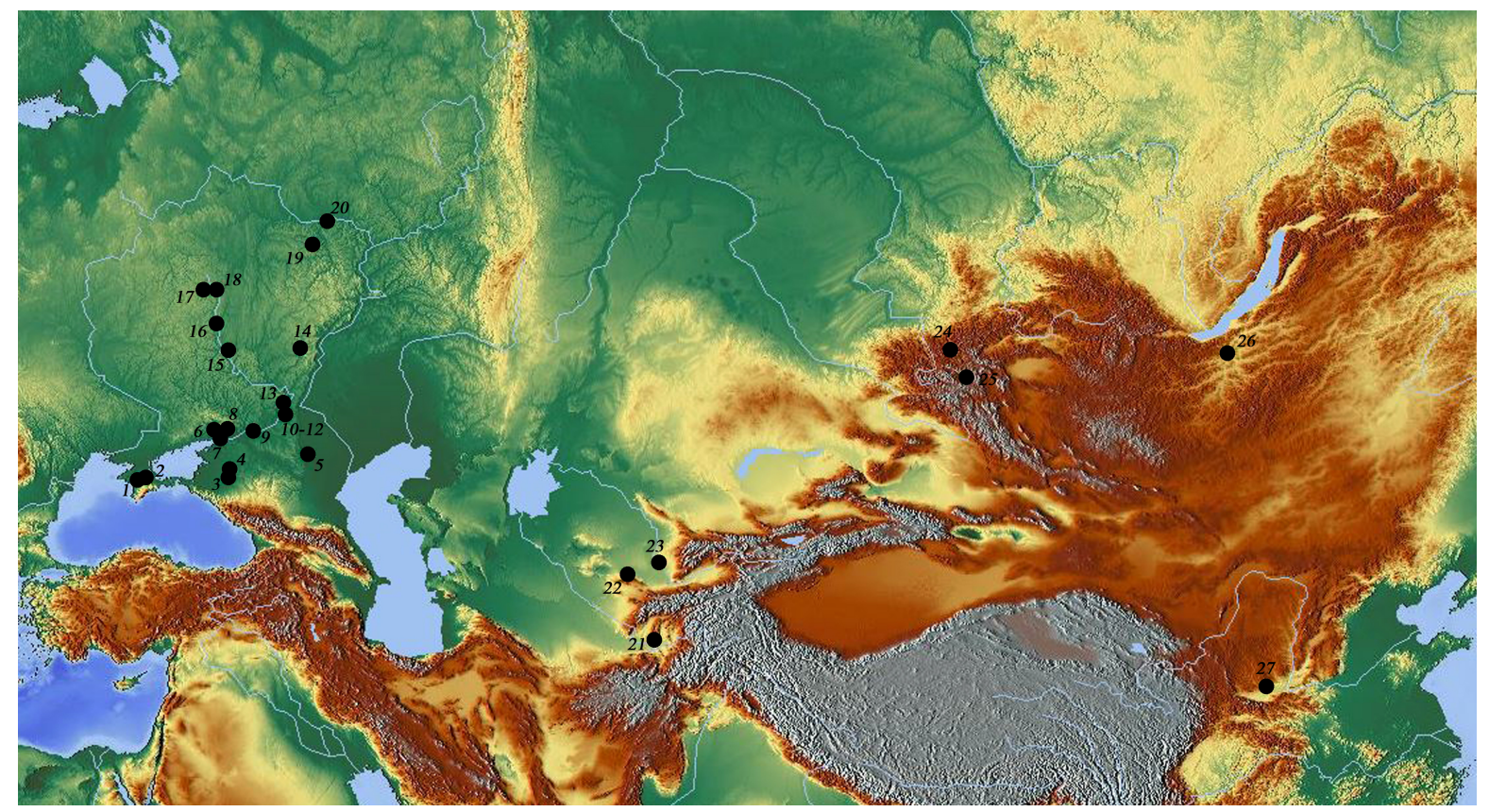

Рис. 5. Места находок стержневых псалиев:

1 - Неаполь Скифский; 2 - Нейзац; 3 - Зубовско-Воздвиженская группа; 4 - Золотое кладбище; 5 - Яшкуль; 6 - Царский; 7 - Дачи; 8 - Кобяково; 9 - Новый; 10 - Октябрьский $\mathrm{V} ; 11$ - Жутово; 12 - Ковалёвка; 13 - Вербовский; 14 - Нижняя Добринка; 15 - Антиповский клад; 16 - І Чертовицкий; 17 - Вязовский; 18 - Ново-Никольский; 19 - Андреевский кург; 20 - Писеральский; 21 - Тахти-Сангин; 22 - Орлатский; 23 - Шаушукум; 24 - Пазырык; 25 - Уландрык; 26 - Ильмовая падь; 27 - Янлин мавзолей

Fig. 5. Finds of cheek-pieces of rod type:

1 - Neapol Skifskiy; 2 - Neyzats; 3 - Zubovsko-Vozdvizhenskaya group; 4 - Zolotoe kladbishche; 5 - Yashkul; 6 -Tsarskiy; 7 - Dachi; 8 - Kobyakovo; 9 - Novyy; 10 - Oktyabrskiy V; 11 - Zhutovo; 12 - Kovalevka; 13 - Verbovskiy; 14 - Nizhnyaya Dobrinka; 15 - Antipovskiy klad; 16 - I Chertovitskiy; 17 - Vyazovskiy; 18 - Novo-Nikolskiy; 19 - Andreevskiy kurgan; 20 - Piseralskiy; 21 - Tahti-Sangin; 22 - Orlatskiy; 23 - Shaushukum; 24 - Pazyryk; 25 - Ulandryk; 26 - Ilmovaya pad; 27 - Hanyang Mausoleum 


\section{СПИСОК СОКРАЩЕНИЙ}

КСИА - Краткие сообщения института археологии.

$P A$ - Российская археология.

$C A-$ Советская археология.

\section{СПИСОК ЛИТЕРАТУРЫ}

1. Антипенко, А. В. Типология псалий I-IV вв. н.э. (по материалам погребальных памятников Северного Причерноморья) / А. В. Антипенко // Материалы по археологии, истории и этнографии Таврии. - Симферополь : Соло-Рич, 2016. - Вып. ХХІ. С. 84-109.

2. Беспалый, Е. И. Древнее население междуречья Дона и Кагальника. В 2 т. Т. 2: Курганный могильник у с. Новоалександровка / Е. И. Беспалый, С. И. Лукьяшко. - Ростов н/Д : Изд-во ЮНЦ РАН, 2018. $-240 \mathrm{c}$.

3. Власкин, М. В. Уздечный набор с тамгообразными псалиями из могильника «Царского» / М. В. Власкин // Историко-археологические исследования в г. Азове и на Нижнем Дону в 1989 г. Азов : Азов. музей-заповедник, 1990. - Вып. 9. C. 64-68.

4. Глебов, В. П. К полемике о проблемах становления среднесарматской культуры / В. П. Глебов // Раннесарматская и среднесарматская культуры: проблемы соотношения : материалы семинара Центра изучения истории и культуры сарматов. - Волгоград : Изд-во ВолГУ, 2006. - Вып. 1. - С. 59-68.

5. Глебов, В. П. О культурно-этнической принадлежности сарматского погребения у пос. Яшкуль (гр. 37, к. 1) / В. П. Глебов // Проблемы археологии Нижнего Поволжья : II Междунар. Нижневолж. археолог. конф. : тез. докл. - Волгоград : Изд-во ВолГУ, 2007. - С. 97-103.

6. Горелик, М. В. Оружие древнего Востока (IV тысячелетие - IV в. до н.э.) / М. В. Горелик. М. : Восточ. лит., 1993. -352 с.

7. Гришаков, В. В. Андреевский курган в системе археологических культур раннего железного века Восточной Европы / В. В. Гришаков, С. Э. Зубов. - Казань : Ин-т истории АН РТ, 2009. $-173 \mathrm{c}$.

8. Гугуев, В. К. Парадный конский убор из кургана 10 Кобяковского могильника / В. К. Гугуев // Донские древности. - Азов : Азов. музей-заповедник, 1992. - Вып. 1. - С. 101-114.

9. Гущина, И. И. Случайная находка в Воронежской области / И. И. Гущина // СА. - 1961. № 2. - С. 241-246.

10. Гущина, И. И. Погребения зубовско-воздвиженского типа из раскопок Н.И. Веселовского в При- кубанье (І в. до н. э. - начало II в. н. э.) / И. И. Гущина, И. П. Засецкая // Труды ГИМ. Вып. 70. Археологические исследования на юге Восточной Европы. М. : ГИМ, 1989. - С. 71-141.

11. Гущина, И. И. «Золотое кладбище» Римской эпохи в Прикубанье / И. И. Гущина, И. П. Засецкая. - СПб. : Фарн, 1994. - 172 с.

12. Древности Чардары (Археологические исследования в зоне Чардаринского водохранилища) / А. Г. Максимова, М. С. Мерщиев, Б. И. Вайнберг, Л. М. Левина. - Алма-Ата : Изд-во Наука КазССР, 1968. -265 c.

13. Зайцев, Ю. П. Элитный некрополь 2 в. н.э. у центральных ворот Неаполя Скифского / Ю. П. Зайцев, В. И. Мордвинцева // Древняя Таврика. - Симферополь : Универсум, 2007. - С. 81-109.

14. Зубов, С. Э. Этнокультурные процессы в Западном Поволжье на рубеже раннего железного века и раннего средневековья: проблемы хронологии и этнической атрибуции памятников писеральско-андреевского типа / С. Э. Зубов, А. В. Михеев // Южный Урал и сопредельные территории в скифо-сарматское время : сб. ст. к 70-летию А.Х. Пшеничнюка. -Уфа : Гилем, 2006. - С. 239-246.

15. Ильюков, Л. С. Сарматы междуречья Сала и Маныча / Л. С. Ильюков, М. В. Власкин. - Ростов н/Д. : Изд-во Рост. ун-та, 1992. - 288 с.

16. Ильясов, Дж. Я. Об изображении на роговом предмете с городища Калалы-Гыр 2 / Дж. Я. Ильясов // PA. - 2013. - № 2. - C. 96-104.

17. Клепиков, В. М. Сарматские погребения могильника Ковалевка: чужие среди своих? / В. М. Клепиков // Вестник Волгоградского государственного университета. Серия 4, История. Регионоведение. Международные отношения. - 2019. - Т. 24, № 1. C. 35-46. DOI: https://doi.org/10.15688/jvolsu4.2019.1.3.

18. Коновалов, П. Б. Хунну Забайкалья (Погребальные памятники) / П. Б. Коновалов. - Улан-Удэ : Бурят. книж. изд-во, 1976. - 248 с.

19. Литвинский, Б. А. Бактрийцы на охоте / Б. А. Литвинский // Записки Восточного отделения Российского археологического общества. Новая серия. - СПб. : Петербург. Востоковедение, 2002. - Т. 1 (XXVI). - С. 181-213.

20. Мавзолей Хань Ян. Собрание экспонатов из Янлина эпохи Хань. - Пекин : Изд-во Вэньу чубаньшэ, 2006. - (На кит. яз.).

21. Маслов, В. Е. О датировке изображений на поясных пластинах из Орлатского могильника / В. Е. Маслов // Евразийские древности. 100 лет Б.Н. Гракову : архивные материалы, публикации, статьи. - М. : Ин-т археологии РАН. - 1999. - С. 219-236.

22. Матренин, С. С. Псалии кочевников Алтая хуннуско-сяньбийско-жужанского времени: классификация и типология / С. С. Матренин // Известия АлтГУ. Исторические науки и археология. - 2018. - 
№2 (100). - C. 167-173. - DOI: https://doi.org/10.14258/ izvasu(2018)2-28.

23. Медведев, А. П. Сарматы и лесостепь (по материалам Подонья) / А. П. Медведев. - Воронеж : Изд-во ВГУ, 1990. - 220 с.

24. Медведев, А. П. Сарматы в верховьях Танаиса / А. П. Медведев. - М. : Таус, 2008. - 252 с.

25. Мордвинцева, В. И. Набор фаларов из кургана 28 могильника Жутово Волгоградской области / В. И. Мордвинцева // Нижневолжский археологический вестник. - 1999. - Вып. 2- С. 42-51.

26. Мордвинцева, В. И. Полихромный звериный стиль. / В. И. Мордвинцева. - Симферополь : Универсум, 2003. - $216 \mathrm{c.}$

27. Мордвинцева, В. И. Древнее золото Поволжья: из фондов Волгоградского областного краеведческого музея / В. И. Мордвинцева, Н. В. Хабарова. - Симферополь : Тарпан, 2006. -140 с.

28. Мыськов, Е. П. Погребение сарматской знати с Есауловского Аксая / Е. П. Мыськов, А.В. Кияшко, А. С. Скрипкин // Нижневолжский археологический вестник. - 1999. - Вып. 2. - С. 149-167.

29. Никаноров В. П. Изображения воинов из Орлатского могильника / В. П. Никаноров, Ю. С. Худяков // Евразия: культурное наследие древних цивилизаций. Вып. 2. Горизонты Евразии. - Новосибирск : [б. и.], 1999.- C. 141-154.

30. Очир-Горяева, М. А. Погребение воина-всадника из курганной группы Яшкуль / М. А. Очир-Горяева // Бюллетень Калмыцкого научного центра PAH. -2019. - Вып. 4. - C. 5-60. - DOI: https://doi.org/ 10.22162/2587-6503-2019-4-12-5-60.

31. Пугаченкова, Г. А. Из художественной сокровищницы Среднего Востока. / Г. А. Пугаченкова. - Ташкент : Изд-во лит. и искусства, 1987. - 224 с.

32. Пугаченкова, Г. А. Древности Мианкаля. Из работ Узбекистанской искусствоведческой экспедиции / Г. А. Пугаченкова. - Ташкент : Фан, 1989. - 204 с.

33. Сергацков, И. В. Проблема формирования среднесарматской культуры / И. В. Сергацков // Археология Волго-Уральского региона в эпоху раннего железного века и средневековья. - Волгоград : Изд-во ВолГУ, 1999. - С. 137-155.

34. Сергацков, И. В. Сарматское погребение на севере Волгоградской области / И. В. Сергацков, П. Е. Захаров // РА. - 2006. - № 1. - С. 117-123.

35. Симоненко, А. В. Сарматские всадники Северного Причерноморья / А. В. Симоненко. - СПб. : Фак. филологии и искусств СПбГУ ; Нестор-История, 2009. $-328 \mathrm{c}$.

36. Скрипкин, А. С. Новые аспекты в изучении истории материальной культуры сарматов / А. С. Скрипкин // Нижневолжский археологический вестник. - 2000. - Вып. 3. - С. 17-40.

37. Скрипкин, А. С. Сарматы / А. С. Скрипкин. - Волгоград : Изд-во ВолГУ, 2017. - 293 с.
38. Тишкин, А. А. Горный Алтай в хуннуское время: культурно-хронологический анализ археологических материалов / А. А. Тишкин, В. В. Горбунов // РА. - 2006. - № 3. - С. 31-140.

39. Трейстер, М. Ю. «Импорты» из Центральной Азии и Сибири в погребальных памятниках Азиатской Сарматии II-I вв. до н.э. / М. Ю. Трейстер // Проблемы истории, филологии, культуры. 2019. - № 4. - C. 180-239. - DOI: https://doi.org/ 10.18503/1992-0431-2019-4-66-180-239.

40. Храпунов, И. Н. Погребения II в. н.э. из могильника Нейзац / И. Н. Храпунов // Проблемы истории, филологии и культуры. - 2015. - № 1(47). C. 216-240.

41. Шилов, В. П. К проблеме взаимоотношений кочевых племен и античных городов Северного Причерноморья в сарматскую эпоху / В. П. Шилов // КСИА. - 1973. - Вып. 138. - С. 60-65.

42. Щукин, М. Б., Некоторые замечания к вопросу о хронологии Зубовско-Воздвиженской группы и проблема ранних аланов / М. Б. Щукин // Античная цивилизация и варварский мир. В 2ч. Ч. 1 : материалы III археол. семинара. - Новочеркасск : [б. и.], 1992.-С. 103-130.

\section{REFERENCES}

1. Antipenko A.V. Tipologiya psaliy I-IV vv. n.e. (po materialam pogrebalnykh pamyatnikov Severnogo Prichernomorya) [A Typology of CheekPieces from the Age of the Sarmatians (According to the Materials of Funeral Sites in the Northern Black Sea Area)]. Materialy po arkheologii, istorii $i$ etnografii Tavrii [Materials in Archaeology, History and Ethnography of Tauria]. Simferopol, Solo-Rich, 2016, iss. XXI, pp. 84-109.

2. Bespalyy E.I., Lukyashko S.I. Drevnee naselenie mezhdurechya Dona $i$ Kagalnika. $V 2 t$. T. 2: Kurgannyy mogilnik u s. Novoaleksandrovka [Ancient Population of the Interfluve of the Don and the Kagalnik. In 2 Vols. Vol. 2: Burial Mound near the Village of Novoaleksandrovka]. Rostov-on-Don, Izd-vo YuNTs RAN, 2018. 240 p.

3. Vlaskin M.V. Uzdechnyy nabor s tamgoobraznymi psaliyami iz mogilnika «Tsarskogo» [Bridle Set with Tamgo-Shaped Cheek-Pieces from the Burial Ground "Tsarskoe"]. Istoriko-arkheologicheskie issledovaniya v g. Azove i na Nizhnem Donu v $1989 \mathrm{~g}$. [Historical and Archaeological Research in Azov and Lower Don in 1989]. Azov, Azovskiy muzey-zapovednik, 1990, iss. 9, pp. 64-68.

4. Glebov V.P. K polemike o problemakh stanovleniya srednesarmatskoy kultury [To the Polemic About the Problems of the Formation of the Middle Sarmatian Culture]. Rannesarmatskaya $i$ 
srednesarmatskaya kultury: problemy sootnosheniya: materialy seminara Tsentra izucheniya istorii $i$ kultury sarmatov [Early Sarmatian and Middle Sarmatian Cultures: Correlation Problems. Proceedings of the Seminar of the Center for the Study of the History and Culture of Sarmatians]. Volgograd, Izd-vo VolGU, 2006, iss. 1, pp. 59-68.

5. Glebov V.P. O kulturno-etnicheskoy prinadlezhnosti sarmatskogo pogrebeniya $u$ pos. Yashkul (gr. 37, k. 1) [On the Cultural and Ethnic Affiliation of the Sarmatian Burial near Yashkul village (gr. 37, m. 1)]. Problemy arkheologii Nizhnego Povolzhya: II Mezhdunar. Nizhnevolzh. arkheolog. konf.: tez. dokl. [Problems of Archeology of the Lower Volga. $2^{\text {nd }}$ International Lower Volga Archaeological Conference. Abstracts]. Volgograd, Izd-vo VolGU, 2007, pp. 97-103.

6. Gorelik M.V. Oruzhie drevnego Vostoka (IV tysyacheletie $-I V v$. do n.e.) [Weapons of the Ancient East $\left(4^{\text {th }}\right.$ Millennium $-4^{\text {th }}$ Century BC) $]$. Moscow, Vostochnaya literatura Publ., 1993. 352 p.

7. Grishakov V.V., Zubov S.E. Andreevskiy kurgan $v$ sisteme arkheologicheskikh kultur rannego zheleznogo veka Vostochnoy Evropy [Andreevka Burial Mound in the System of Archaeological Cultures of the Early Iron Age of Eastern Europe]. Kazan, Institut istorii AN RT, 2009. 173 p.

8. Guguev V.K. Paradnyy konskiy ubor iz kurgana 10 Kobyakovskogo mogilnika [Ceremonial Horse Headdress from Barrow 10 of Kobyakovsky Burial Ground]. Donskie drevnosti [Don Antiquities]. Azov, Azovskiy muzey-zapovednik, 1992, iss. 1, pp. 101-114.

9. Gushchina I.I. Sluchaynaya nakhodka v Voronezhskoy oblasti [A Random find in Voronezh Region]. SA [Soviet Archaeology], 1961, no. 2, pp. 241-246.

10. Gushchina I.I., Zasetskaya I.P. Pogrebeniya zubovsko-vozdvizhenskogo tipa iz raskopok N.I. Veselovskogo v Prikubanye (I v. do n.e. - nachalo II v. n.e.) [Burials of the Zubovsko-Vozdvizhensk Type from the Excavations of N.I. Veselovsky in the Kuban Region (I Century BC-Beginning of II Century AD)]. Trudy GIM. Vyp. 70. Arkheologicheskie issledovaniya na yuge Vostochnoy Evropy [Proceedings of the State Historical Museum. Iss. 70. Archaeological Research in the South of Eastern Europe]. Moscow, GIM, 1989, pp. 71-141.

11. Gushchina I.I., Zasetskaya I.P. «Zolotoe kladbishche» Rimskoy epohi v Prikubanye ["Golden Cemetery" of the Roman Age in the Kuban Basin]. Saint Petersburg, Farn Publ., 1994. 172 p.

12. Maksimova A.G., Mershchiev M.S., Vaynberg B.I., Levina L.M. Drevnosti Chardary (Arkheologicheskie issledovaniya $v$ zone Chardarinskogo vodokhranilishcha) [Antiquities of Chardara
(Archaeological Research in the Area of the Chardara Reservoir)]. Alma-Ata, Izd-vo Nauka KazSSR, 1968. 265 p.

13. Zaytsev Yu.P., Mordvintseva V.I. Elitnyy nekropol 2 v. n.e. u tsentralnykh vorot Neapolya Skifskogo [The Elite Necropolis of the $2^{\text {nd }}$ Century AD near the Central Gate of the Scythian Neapolis]. Drevnyaya Tavrika [Ancient Taurica]. Simferopol, Universum Publ., 2007, pp. 81-109.

14. Zubov S.E., Mikheev A.V. Etnokulturnye protsessy v Zapadnom Povolzhye na rubezhe rannego zheleznogo veka i rannego srednevekovya: problemy khronologii i etnicheskoy atributsii pamyatnikov piseralsko-andreevskogo tipa [Ethnocultural Processes in the Western Volga Region at the Turn of the Early Iron Age and the Early Middle Ages: Problems of Chronology and Ethnic Attribution of Monuments of the Piseral-Andreev Type]. Yuzhnyy Ural $i$ sopredelnye territorii $v$ skifo-sarmatskoe vremya: sb. st. $k$ 70-letiyu A.Kh. Pshenichnyuka [The Southern Urals and Adjacent Territories in the Scythian-Sarmatian Time. Collection of Articles to the $70^{\text {th }}$ Anniversary of A.Kh. Pshenichnyuk]. Ufa, Gilem Publ., 2006, pp. 239-246.

15. Ilyukov L.S., Vlaskin M.V. Sarmaty mezhdurechya Sala i Manycha [Sarmatians Between the Sal and Manych Rivers]. Rostov-on-Don, Izd-vo Rostovskogo universiteta, 1992. 288 p.

16. Ilyasov Dzh.Ya. Ob izobrazhenii na rogovom predmete s gorodishcha Kalaly-Gyr 2 [Concerning the Image on the Horn Item from Kalaly-Gyr 2]. $R A$ [Russian Archaeology], 2013, no. 2, pp. 96-104.

17. Klepikov V.M. Sarmatskie pogrebeniya mogilnika Kovalevka: chuzhie sredi svoikh? [Sarmatian Burials of the Kovalevka Burial Mound: Strangers Among Friends?]. Vestnik Volgogradskogo gosudarstvennogo universiteta. Seriya 4, Istoriya. Regionovedenie. Mezhdunarodnye otnosheniya [Science Journal of Volgograd State University. History. Area Studies. International Relations], 2019, vol. 24, no. 1, pp. 35-46. DOI: https://doi.org/10.15688/ jvolsu4.2019.1.3

18. Konovalov P.B. Khunnu Zabaykalya (Pogrebalnye pamyatniki) [Huns of Transbaikalia (Funeral Monuments)]. Ulan-Ude, Buryatskoe knizhnoe izd-vo, 1976. 248 p.

19. Litvinskiy B.A. Baktriytsy na okhote [Bactrians on the Hunt]. Zapiski Vostochnogo otdeleniya Rossiyskogo arkheologicheskogo obshchestva. Novaya seriya [Memoirs of the Oriental Department of the Russian Archaeological Society. New Episode]. Saint Petersburg, Peterburgskoe Vostokovedenie Publ., 2002, vol. 1 (XXVI), pp. 181-213.

20. Hanyang Mausoleum. Hanyang Ling Museum collection. Beijing, Izd-vo Venyu chubanshe, 2006. (in Chinese). 
21. Maslov V.E. O datirovke izobrazheniy na poyasnykh plastinakh iz Orlatskogo mogilnika [About the Date of Images on the Belt Plates from Orlat Cemetery]. Evraziyskie drevnosti. 100 let B.N. Grakovu: arkhivnye materialy, publikatsii, statyi [Eurasian Antiquities. The Centenary of Boris N. Grakov. Archival Materials, Publications, Papers]. Moscow, Institut arkheologii RAN, 1999, pp. 219-236.

22. Matrenin S.S. Psalii kochevnikov Altaya khunnusko-syanbiysko-zhuzhanskogo vremeni: klassifikatsiya i tipologiya [Psalium of the Altai Nomads of Xiongnu-Xianbei-Zhuzhan Time: Classification and Typology]. Izvestiya AltGU. Istoricheskie nauki $i$ arkheologiya [Izvestiya of Altai State University Journal. Historical Sciences and Archeology], 2018, no. 2 (100), pp. 167-173. DOI: https://doi.org/10.14258/ izvasu(2018)2-28.

23. Medvedev A.P. Sarmaty i lesostep (po materialam Podonya) [Sarmatians and Forest-Steppe (Based on the Don Region)]. Voronezh, Izd-vo VGU, 1990. $220 \mathrm{p}$.

24. Medvedev A.P. Sarmaty v verkhovyakh Tanaisa [Sarmatians in the Upper Reaches of the Tanais]. Moscow, Taus Publ., 2008. 252 p.

25. Mordvintseva V.I. Nabor falarov iz kurgana 28 mogilnika Zhutovo Volgogradskoy oblasti [Set of Falars from Mound 28 of Zhutovo Burial Ground of Volgograd Region]. Nizhnevolzhskiy arkheologicheskiy vestnik [The Lower Volga Archaeological Bulletin], 1999, iss. 2, pp. 42-51.

26. Mordvintseva V.I. Polikhromnyy zverinyy stil [The Polychrome Animal Style]. Simferopol, Universum Publ., 2003. 216 p.

27. Mordvintseva V.I., Khabarova N.V. Drevnee zoloto Povolzhya: iz fondov Volgogradskogo oblastnogo kraevedcheskogo muzeya [Ancient Gold of the Volga Region. The Collection of Volgograd Regional Museum of Local Lore]. Simferopol, Izd-vo Tarpan, 2006. $140 \mathrm{p}$.

28. Myskov E.P., Kiyashko A.V., Skripkin A.S. Pogrebenie sarmatskoy znati s Esaulovskogo Aksaya [The Burial of the Sarmatian Nobility from the Yesaulovsky Aksay River]. Nizhnevolzhskiy arkheologicheskiy vestnik [The Lower Volga Archaeological Bulletin], 1999, iss. 2, pp. 149-167.

29. Nikanorov V.P., Khudyakov Yu.S. Izobrazheniya voinov iz Orlatskogo mogilnika [Images of Soldiers from the Orlatsky Burial Ground]. Evraziya: kulturnoe nasledie drevnikh tsivilizatsiy. Vyp. 2. Gorizonty Evrazii [Eurasia: Cultural Heritage of Ancient Civilizations. Iss. 2. The Horizons of Eurasia], Novosibirsk, [s. n.], 1999, pp. 141-154.

30. Ochir-Goryaeva M.A. Pogrebenie voinavsadnika iz kurgannoy gruppy Yashkul [Burial of the Warrior-Rider from Yashkul Barrow Group]. Byulleten
Kalmytskogo nauchnogo tsentra RAN. Elista [Bulletin of the Kalmyk Scientific Center of the RAS], 2019, iss. 4, pp. 5-60. DOI: https://doi.org/10.22162/ 2587-6503-2019-4-12-5-60.

31. Pugachenkova G.A. Iz khudozhestvennoy sokrovishchnitsy Srednego Vostoka [From the Art Treasury of the Middle East]. Tashkent, Izd-vo literatury $\mathrm{i}$ iskusstva, 1987. $224 \mathrm{p}$.

32. Pugachenkova G.A. Drevnosti Miankalya. Iz rabot Uzbekistanskoy iskusstvovedcheskoy ekspeditsii [Antiquities of Miancal. From the Works of the Uzbekistan Art History Expedition]. Tashkent, Fan Publ., 1989. 204 p.

33. Sergatskov I.V. Problema formirovaniya srednesarmatskoy kultury [The Problem of the Formation of the Middle Sarmatian Culture]. Arkheologiya Volgo-Uralskogo regiona v epokhu rannego zheleznogo veka $i$ srednevekovya [Archeology of the Volga-Ural Region in the Era of the Early Iron Age and the Middle Ages]. Volgograd, Izd-vo VolGU, 1999, pp. 137-155.

34. Sergatskov I.V., Zakharov P.E. Sarmatskoe pogrebenie na severe Volgogradskoy oblasti [Sarmatian Burial in the North of the Volgograd Region]. RA [Russian Archaeology], 2006, no. 1, pp. 117-123.

35. Simonenko A.V. Sarmatskie vsadniki Severnogo Prichernomorya [Sarmatian Riders of the North Pontic Region]. Saint Petersburg, Fakultet filologii i iskusstv SPbGU, Nestor-Istoriya Publ., 2009, 2009. 328 p.

36. Skripkin A.S. Novye aspekty v izuchenii istorii materialnoy kultury sarmatov [New Aspects in the Investigation of the History of Sarmatian Material Culture]. Nizhnevolzhskiy arkheologicheskiy vestnik [The Lower Volga Archaeological Bulletin], 2000, iss. 3, pp. 17-40.

37. Skripkin A.S. Sarmaty [The Sarmatians]. Volgograd, Izd-vo VolGU, 2017. 293 p.

38. Tishkin A.A., Gorbunov V.V. Gornyy Altay v khunnuskoe vremya: kulturno-khronologicheskiy analiz arkheologicheskikh materialov [The Altai Mountains in the Hunnian Period: Cultural and Chronological Analysis of Archaeological Material]. RA [Russian Archaeology], 2006, no. 3, pp. 31-140.

39. Treyster M.Yu. «Importy» iz Tsentralnoy Azii i Sibiri v pogrebalnykh pamyatnikakh Aziatskoy Sarmatii II-I vv. do n.e. ["Imports" from Central Asia and Siberia in the Burials of Asian Sarmatia of the $2^{\text {nd }}-$ $1^{\text {st }}$ Centuries BC]. Problemy istorii, filologii, kultury [Journal of Historical, Philological and Cultural Studies], 2019, no. 4, pp. 180-239. DOI: https://doi.org/ 10.18503/1992-0431-2019-4-66-180-239.

40. Khrapunov I.N. Pogrebeniya II v. n.e. iz mogilnika Neyzats [The $2^{\text {nd }}$ Century AD Graves in the Neyzats Necropolis]. Problemy istorii, filologii $i$ 
kultury [Journal of Historical, Philological and Cultural Studies], 2015, no. 1 (47), pp. 216-240.

41. Shilov V.P. K probleme vzaimootnosheniy kochevykh plemen i antichnykh gorodov Severnogo Prichernomorya $v$ sarmatskuyu epokhu [On the Problem of the Relationship of Nomadic Tribes and Ancient Cities of the Northern Black Sea Region in the Sarmatian Era]. KSIA [Brief Communications of the Institute of Archaeology], 1973, vol. 138, pp. 60-65.
42. Shchukin M.B. Nekotorye zamechaniya k voprosu o khronologii Zubovsko-Vozdvizhenskoy gruppyi problema rannikh alanov [Some Remarks on the Chronology of the Zubovsko-Vozdvizhensk Group and the Problem of the EarlyAlans]. Antichnaya tsivilizatsiya $i$ varvarskiy mir. V 2 ch. Ch. 1: materialy III arkheol. seminara [Ancient Civilization and the Barbarian World. In 2 parts. Part 1. Proceedings of the $3^{\text {rd }}$ Archaeological Seminar]. Novocherkassk, [s. n.], 1992, pp. 103-130.

\section{Information About the Authors}

Valeriy M. Klepikov, Candidate of Sciences (History), Associate Professor, Department of Russian and World History, Archaeology, Volgograd State University, Prosp. Universitetsky, 100, 400062 Volgograd, Russian Federation, valery.klepikov@volsu.ru, valery.klepikov@mail.ru, https://orcid.org/0000-0003-2891-7366

Mikhail V. Krivosheev, Candidate of Sciences (History), Head of the Laboratory of Archaeological Research, Volgograd State University, Prosp. Universitetsky, 100, 400062 Volgograd, Russian Federation, arhlab@volsu.ru,tyaf@mail.ru, https://orcid.org/0000-0003-4847-8209

\section{Информация об авторах}

Валерий Михайлович Клепиков, кандидат исторических наук, доцент кафедры отечественной и всеобщей истории, археологии, Волгоградский государственный университет, просп. Университетский, 100, 400062 г. Волгоград, Российская Федерация, valery.klepikov@volsu.ru, valery.klepikov@mail.ru, https://orcid.org/0000-0003-2891-7366

Михаил Васильевич Кривошеев, кандидат исторических наук, заведующий лабораторией археологических исследований, Волгоградский государственный университет, просп. Университетский, 100, 400062 г. Волгоград, Российская Федерация, arhlab@volsu.ru, tyaf@mail.ru, https://orcid.org/0000-0003-4847-8209 